\title{
Dual-system concept for stormwater control in commercial centre
}

\author{
Darrien Y.S. Mah ${ }^{1^{*}}$, Janice Lynn Ayog ${ }^{2}$ and Afdal Haziq Mohamad Salehe ${ }^{3}$ \\ Faculty of Engineering, Universiti Malaysia Sarawak, 94300 Kota Samarahan, Sarawak, Malaysia ${ }^{1}$ \\ Faculty of Engineering, Universiti Malaysia Sabah, 88400 Kota Kinabalu, Sabah, Malaysia ${ }^{2}$ \\ Syarikat Haziq Jaya Pvt Ltd, Desa Ilmu, 94300 Kota Samarahan, Sarawak, Malaysia ${ }^{3}$
}

Received: 28-August-2021; Revised: 15-January-2022; Accepted: 16-January-2022

(C)2022 Darrien Y.S. Mah et al. This is an open access article distributed under the Creative Commons Attribution (CC BY) License, which permits unrestricted use, distribution, and reproduction in any medium, provided the original work is properly cited.

\begin{abstract}
This paper describes the stormwater characterization due to a dual stormwater detention system that is tailored for a commercial area. A commercial centre is known to have the area covered with two distinct land uses, namely the shop buildings and tarred road surfaces. Manipulating these land uses for more environmental-friendly urban stormwater management; a novel dual stormwater detention system is introduced within the buildings and roads. Using a case study of a simple one-row shop building, a detention system is proposed under the walkway in front of the shop lots and under the parking spaces in front of the same shops. Storm water management model (SWMM) version 5.0 is used to simulate three scenarios of drainage flow in the study site. Simulations of a single detention system of either under the walkway (Scenario 1) or parking spaces (Scenario 2) are carried out. Scenario 3 is a simulation of a dual system combining the previous two scenarios. Scenario 2 has a catchment of about 10\% of the total commercial centre; Scenario 2 has about $20 \%$ and Scenario 3 has about 30\%. It is found that Scenario 3, namely the dual system with the highest connected water contributing catchment produces the best stormwater control by lowering the post-development peak hydrographs by 1.5 times, thus achieving the nearest to the pre-development condition. The simulations also show that the two separate single detention systems are less effective than the dual system in this case study.
\end{abstract}

\section{Keywords}

Impervious surfaces, Land use, Permeable pavement, Stormwater detention, Underground storage, Urban runoff.

\section{Introduction}

In a congested urban area like a city, its land surface area is covered with buildings and other infrastructures. Little bare or green spaces are available that could absorb stormwater into the ground. Disposal of excess stormwater from the urban area relies on the urban drains, and the urban drainage system is increasingly challenged by the greater amount of rainfall due to climate change in the recent years [1].

Scientists and engineers alike, are working to improve the well-being of urban dwellers. For example, sponge city as a new stormwater management strategy, has been introduced in more and more cities [2]. Pockets of land spaces or manmade structures are constructed to absorb stormwater, like sponges would soak up water [3, 4].

\footnotetext{
*Author for correspondence
}

A dual stormwater system is one of the ways to optimize limited spaces, in which in normal practices, are constructed separately.

A single system may yield little impact on stormwater control at a catchment scale [5]. Combining stormwater control systems in an urban environment, for example, trenches alongside urban trees are reported in favour of unmitigated impervious surfaces [6]. The types of stormwater control combination vary from catchment to catchment [7]. A structure for commercial area may be different than a residential area. Availability of spaces or catchment area is another factor that determines the selection of appropriate measures [8].

This paper explores on a commercial centre, in which its land uses are distinctively made up of shop buildings and tarred roads. Therefore, to be specific, the dual system here is meant for a stormwater system fitted as a part of the building structure, and then coupled with another system as part of the low 
volume road system. The proposed new dual stormwater is described in the next section.

After the introduction, the literature review on stormwater control is described. It is followed by the materials and methods, in which the section covers the type of stormwater control system in the study, selected case study, requirements in urban stormwater management, type of modelling and associated control parameters. Next, results and discussion of the modelling efforts are presented before the conclusion is drawn.

\section{Literature review}

Generally, stormwater control is meant to hold running water from urban surfaces to alleviate problems like flash flooding, erosion and water pollution. Three examples of combined stormwater control systems are presented in Figure 1.

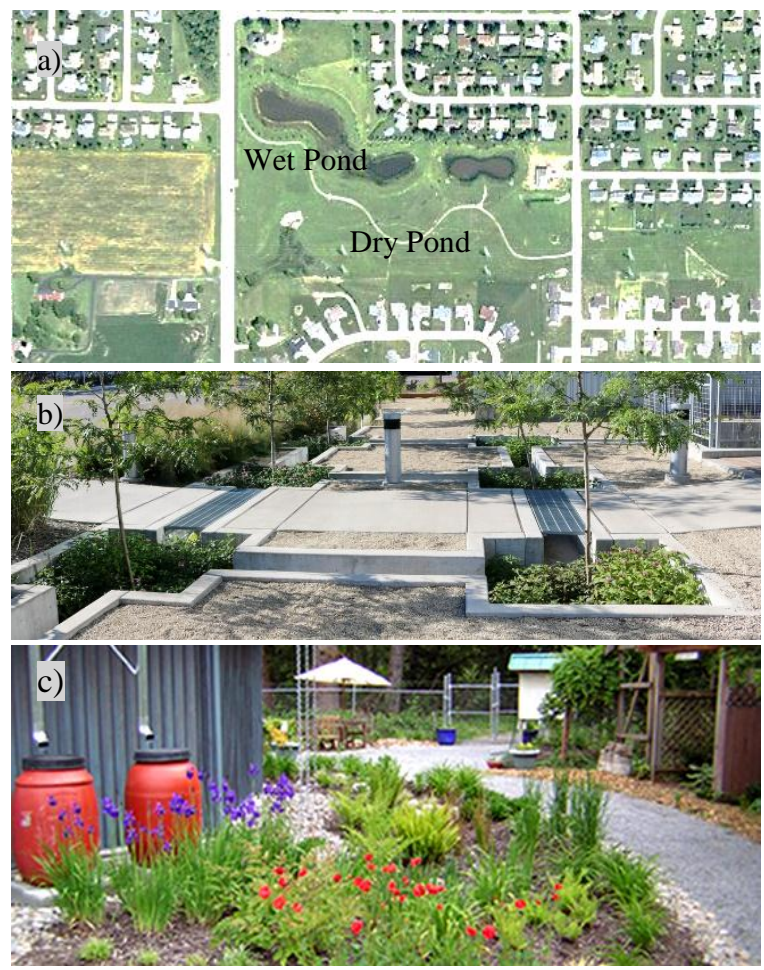

Figure 1 Combined stormwater control systems, a) Dry and wet ponds [9], b) Urban trees and trenches [10], c) Rain barrels and rain garden [11]

A community-scale stormwater control system combining dry and wet ponds is depicted in Figure 1(a). Dry ponds are land surfaces that are purposely lowered to collect water during rainy seasons, whereas wet ponds are permanent structures designed to contain standing water. The dry and wet ponds complement each other in providing a water storing medium for a large area.

A drainage area fitted with a combination of urban trees and trenches is depicted in Figure 1(b). Trees function to capture water through its root system, while trenches alongside the trees allows retention and detention of stormwater simultaneously. Finally, an area of a combined rain barrels and rain garden is depicted in Figure 1(c). Rain barrels are generally used to capture rainwater from rooftops, which then diverted to the rain garden for retention purposes. Compared to the drainage system in Figure 1(a), the tree-trench and rain barrel-garden systems are more suitable for a localized area.

The authors outline the advantages of having a combined stormwater system for the three examples in Table 1. The highlighted dual systems are found to enhance the stormwater control qualities of each other.

Table 1 Advantages of combined systems

\begin{tabular}{lll}
\hline Studies & $\begin{array}{l}\text { Major } \\
\text { system }\end{array}$ & Complementary system \\
\hline Ibrahim[12] & Wet pond & $\begin{array}{l}\text { Dry pond received the } \\
\text { overflow from wet pond as } \\
\text { additional water storage }\end{array}$ \\
\hline $\begin{array}{l}\text { Ebrahimian } \\
\text { et al. [13] }\end{array}$ & Trees & $\begin{array}{l}\text { Trenches provided additional } \\
\text { holding spaces for water } \\
\text { away from the planting } \\
\text { mediums that were saturated } \\
\text { with stormwater }\end{array}$ \\
\hline $\begin{array}{l}\text { Sobirin and } \\
\text { Sutjiningsih }\end{array}$ & Rain & $\begin{array}{l}\text { Rain barrels directed the } \\
\text { stormwater from building } \\
\text { [14] }\end{array}$ \\
& & $\begin{array}{l}\text { roofs surrounding to the rain } \\
\text { garden that could be } \\
\text { infiltrated into the ground. } \\
\text { This reduced the burden of } \\
\text { urban drains }\end{array}$ \\
\hline
\end{tabular}

Buildings that are equipped with stormwater tanks are common practice in capturing stormwater. These are reported in the past studies, for example, Araujo et al. [15] had anticipated the significance of the rainwater harvesting tank within a building; Lestari et al. [16] had illustrated the benefits of having an underground tank in a school complex; Sharma and Gardner [17] maintained that building codes in Australian had increased the installation of stormwater tanks across Australian cities.

On the other hand, tarred road surfaces could be replaced with permeable pavements. Studies like Antunes et al. [18] and Martins et al. [19] had applauded that stormwater harvested from the 
permeable pavements could be recycled for nonpotable water uses. However, the authors could not find any combined building-road stormwater detention systems in the literature.

In the context of this paper, a typical commercial centre (in Figure 2) generally consists of a walkway of $1.5 \mathrm{~m}$ wide and a parking space of about $5 \mathrm{~m}$ long. The walkway is positioned next to a perimeter drain of $0.5 \mathrm{~m}$ wide, which are common features in front of shop buildings. A dual stormwater system is proposed to exploit the surface areas provided by the walkway and parking space for an underground stormwater detention system.

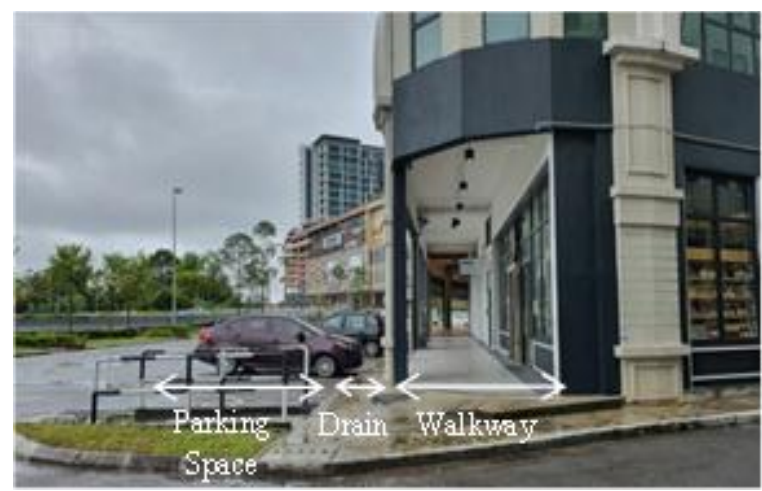

Figure 2 Common layout of Malaysian shop buildings

\section{Materials and methods}

\subsection{Proposed dual system}

The authors are introducing a non-commercialized modular-based stormwater system (Figure 3), developed by the universities affiliated in the Malaysian Comprehensive Universities Network. The concrete-made modular units are coined as microdetention pond, in which each modular unit has a chamber buried underground to hold $0.19 \mathrm{~m}^{3}$ of water per $\mathrm{m}^{2}$ of pavement area.

Stated as System 1 in Figure 3(b), the units could conveniently be fitted into the walkway of shop buildings to receive rainwater from the rooftop via the downpipes. The modular unit has a cover with no service inlet on it. Besides the walkway, the modular units could also be fitted into the parking spaces. Stated as System 2 in Figure 3(b), the cover of the modular unit is equipped with a service inlet that allows infiltration of surface water to its underground chamber. Both System 1 and System 2 discharge water to the perimeter drain.
In a conventional drainage system, water from the rooftop flowing to the ground via the downpipes is generally discharged directly into the drain. The water that is intercepted by the impervious tarred car parking surfaces is directly discharged to the drain as well. In contrast, the newly proposed system captures and holds the water from the roof and parking space close to their sources and eventually releases the water slowly back to the main drainage network [20-22].

a)
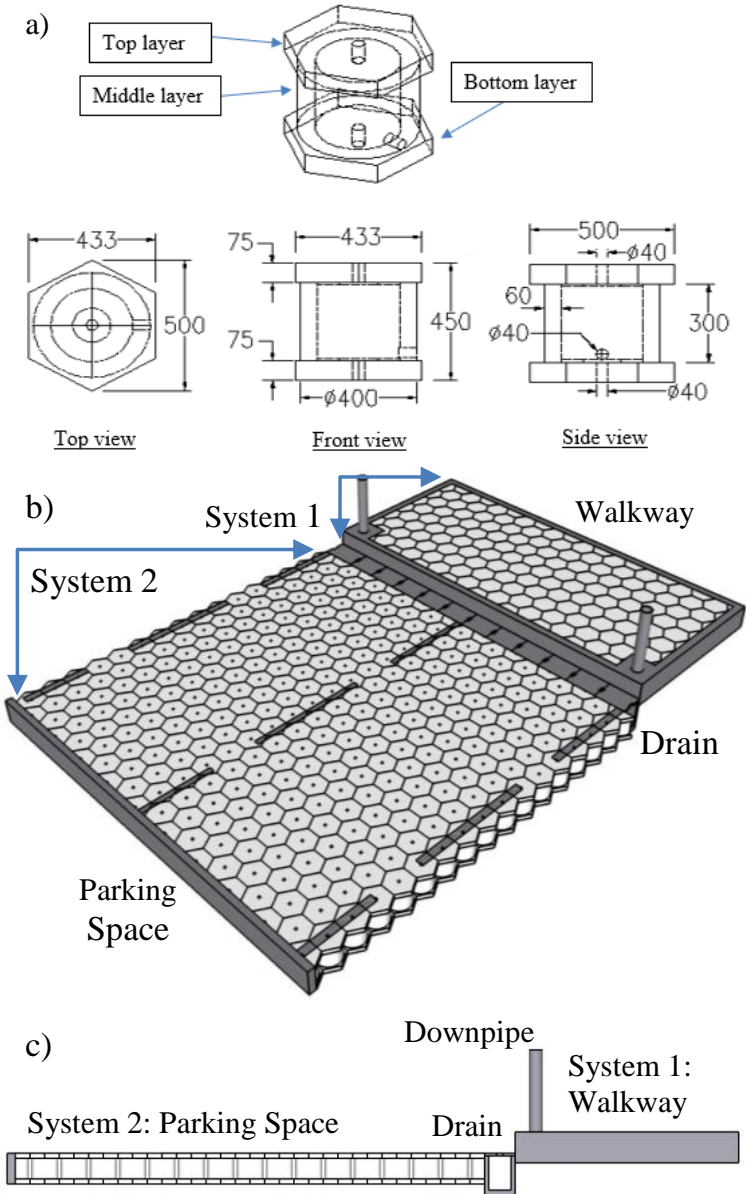

d)

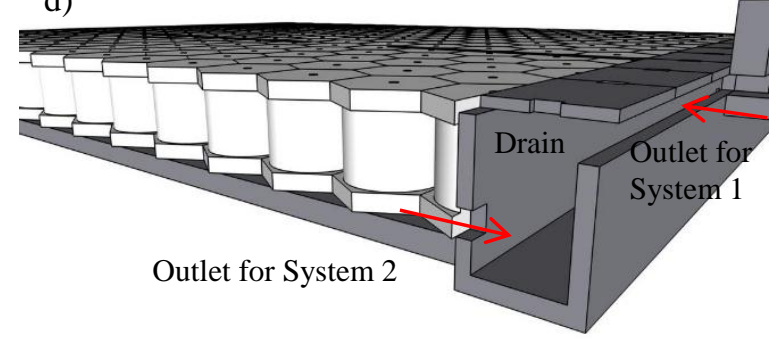

Figure 3 Proposed dual stormwater system, a) Modular units, b) 3D layout, c) Side view and d) Outlets 
The biggest setback of the layout lies in System 1, in which any overflowing from the system shall flood the shop lot. To overcome this issue, System 1 is built $0.3 \mathrm{~m}$ higher than the drain (see Figure $3 \mathrm{c}$ ). In addition, the entrance to the shop lot is made $0.07 \mathrm{~m}$ higher than the walkway. Moreover, the outlets of the System 1 are on the upper part of the drain (see Figure $3 d$ ). This is in contrast with the outlets from System 2, in which these are inserted at the lower part of the drain. As such, water from System 1 could be drained in a cascading manner so that congestion of flow with System 2 could be avoided. The design of the mentioned outlets plays a critical role to ensure no flooding would occur.

\subsection{Case study}

A small commercial centre, known by the locals as Palm Square, is selected. Having a case study allows a representative of an urban area to be investigated for the design and performance of stormwater drainage infrastructure [23]. This commercial centre is located beside Dato Mohd Musa Road in Samarahan, Sarawak (Figure 4). The total area of the commercial centre is around $3,425 \mathrm{~m} 2$, in which the shop buildings occupy $39 \%$ of the total area and the tarred road surfaces occupy the remaining $61 \%$.

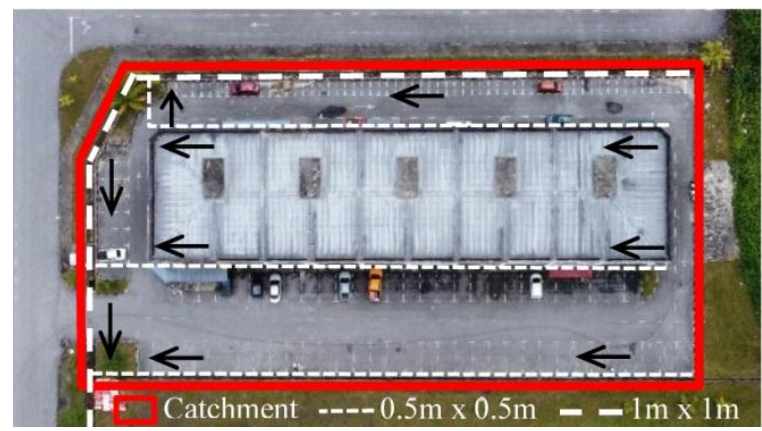

Figure 4 Study area

In this commercial centre, there are ten units of double-storey shops, where each shop's corner lot are sized $18 \mathrm{~m}$ long and $9 \mathrm{~m}$ wide. The intermediate lots are sized $18 \mathrm{~m}$ long and $7 \mathrm{~m}$ wide each. The row of shops is $74 \mathrm{~m}$ long. The existing drainage consists of $0.5 \mathrm{~m} \times 0.5 \mathrm{~m}$ perimeter drain at the front and the back of the shop buildings. These perimeter drains are connected to a $1 \mathrm{~m} \times 1 \mathrm{~m}$ drain surrounding the commercial centre. Such conventional drainage is also termed the post-development system with uncontrolled runoff.

Adding stormwater control systems to the conventional drainage is then termed the postdevelopment system with controlled runoff. Three scenarios are formulated in this study and these are presented in Figure 5.

Scenario 1 takes $666 \mathrm{~m}^{2}$ front roof $(74 \mathrm{~m} \times 9 \mathrm{~m})$ of the shop buildings to drain rainwater to a $21 \mathrm{~m}^{3}$ effective underground storage $(74 \mathrm{~m} \times 1.5 \mathrm{~m} \times 0.19$ $\mathrm{m}^{3} / \mathrm{m}^{2}$ ) under the shop's walkway. Scenario 2 takes $370 \mathrm{~m}^{2}$ car parking spaces $(74 \mathrm{~m} \times 5 \mathrm{~m})$ in front of the shop buildings to drain rainwater to a $70 \mathrm{~m}^{3}$ effective underground storage $(74 \mathrm{~m} \times 5 \mathrm{~m} \times 0.19$ $\mathrm{m}^{3} / \mathrm{m}^{2}$ ) under the parking spaces. Scenarios 1 and 2 are testing a single system each that may or may not be adequate to achieve the desired stormwater control. Combining the two systems, it forms the intended dual system illustrated in Scenario 3.

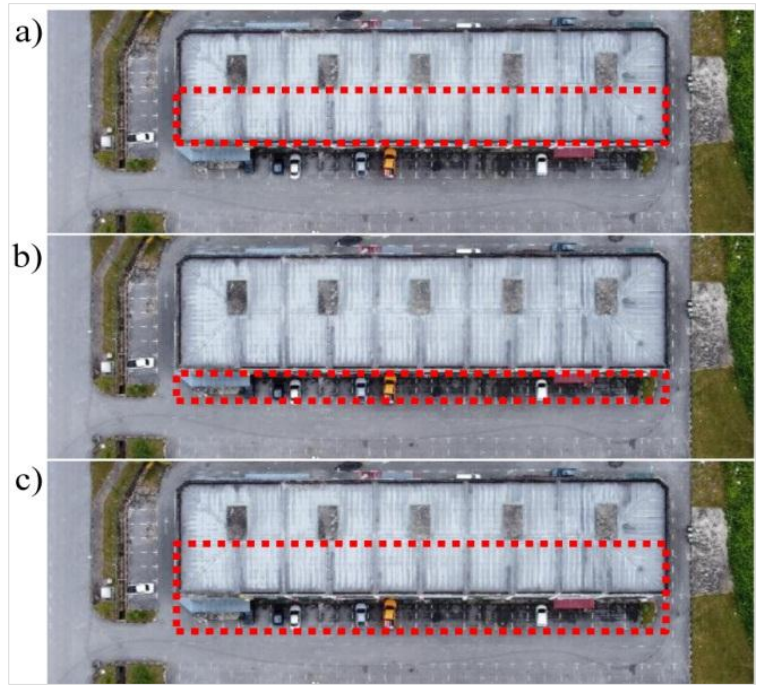

Figure 5 Stormwater control, a) Scenario 1, b) Scenario 2 and c) Scenario 3

\subsection{Urban stormwater management}

The goal of urban stormwater management is illustrated in Figure 6, in which the peak flow hydrograph of post-development with uncontrolled runoff should be lowered [24, 25].

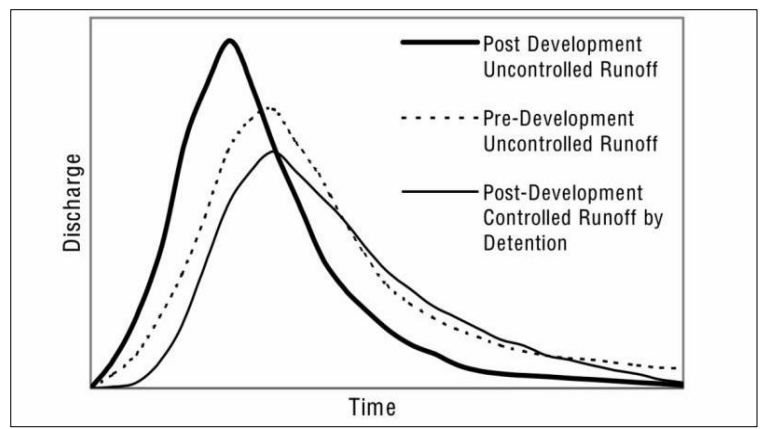

Figure 6 Stormwater control goal [25] 
How much the peak flow hydrograph could be reduced is generally referred to the peak flow hydrograph of pre-development with uncontrolled runoff detention. A reduction more or less nearing the pre-development level is taken as the performance criteria [26].

Flow hydrographs depicted in Figure 6 are the consequences of rainfall and the temporal rainfall variability influences commercial activities [27]. The Urban Stormwater Management Manual for Malaysia [25] recommends that a commercial area should design to 10-year average recurrent interval (ARI). This study explores on 10, 15, 30, 60, 120 and 180 minutes of storm durations. The ARIs and associated different storm durations are reflected in the rainfall intensities, I, being used. The selected storm durations follow the recommendation in [28] to test a stormwater system up to three-hour storm under the tropical climate. The flow of stormwater runoff generated from a catchment is commonly calculated via Rational Method, as presented in Equation 1:

$Q_{\text {Rational Method }}=\frac{\text { C.I. } A_{D}}{360}$

Where,

$Q_{\text {Rational Method }}=$ Catchment flow $\left(\mathrm{m}^{3} / \mathrm{s}\right)$;

$C=$ Runoff coefficient (unitless);

$I=$ Rainfall intensity $(\mathrm{mm} / \mathrm{hr})$; and

$A_{D}=$ Drainage area (ha).

On the other hand, the flow of stormwater runoff in an urban drain is commonly calculated using Manning equation, as presented in Equation 2:

$Q_{\text {Manning Equation }}=\frac{1}{n} A_{F} R^{2 / 3} S_{F}{ }^{1 / 2}$

Where,

$Q_{\text {Manning equation }}=$ Drain flow $\left(\mathrm{m}^{3} / \mathrm{s}\right)$;

$n=$ Manning's roughness coefficient (unitless);

$A_{F}=$ Flow area of drain $\left(\mathrm{m}^{2}\right)$;

$R=$ Hydraulic radius of drain (m); and

$S_{F}=$ Friction slope of drain $(\mathrm{m} / \mathrm{m})$.

\subsection{Drainage modelling}

Storm water management model (SWMM) drainage modelling starts with the rainfall. The type of design rainfall data employed in this study is outlined in the previous section. Rainfall falls on a catchment and from the catchment, water flows into man-made channel and facilities before leaving the catchment via a final discharge point.

Catchment flow in SWMM is computed based on the catchment characteristics. Parameters like width $(W)$, slope $(S)$, depression storage $(d p)$ and depth of water over the catchment $(d)$ could be measured from the study site. The remaining parameter, Manning's $n$ value, has been set as 0.4 for pre-development condition, and 0.8-1.0 for post-development condition [24]. Based on the past study conducted by [29], an $n$ value of 1.0 was applied for the roof and road catchments, assuming that water losses from the impervious roof and road surfaces were negligible. The catchment flow is governed by Equation 3:

$Q_{S W M M}$ Catchment $=W \frac{1.49}{n}\left(d-d_{p}\right)^{5 / 3} S_{C}{ }^{1 / 2}$

Where,

$Q_{S W M M \text { Catchment }}=$ Catchment flow $\left(\mathrm{m}^{3} / \mathrm{s}\right)$;

$W=$ Width of catchment (m);

$S c=$ Slope of catchment $(\mathrm{m})$;

$n=$ Manning roughness value (unitless);

$d_{p}=$ Maximum depression storage $(\mathrm{m})$;

$d=$ Depth of water over the catchment (m).

SWMM represents stretches of urban drain as nodes and links. Nodes define the locality and elevation whereas links define the geometry of the drain. The model routes the flow from node to node until the flow reaches the final discharge point, taking into account the distance in between two nodes $(x)$, crosssectional area of the drain $(A)$, flow geometry $(\alpha)$ and surface roughness of drain $(m)$. These parameters are measurable from the study site. The time step of flow routing is a variable. Following the recommendation of [29], a time step of $30 \mathrm{~s}$ was chosen, and was considered adequate for drains in an urban setting. The flow that enters the drain is governed by Equation 4:

$Q_{S W M M \text { Drain }}=\frac{\partial A}{\partial t}+\alpha m A^{(m-1)} \frac{\partial A}{\partial x}$

Where,

$Q_{\text {SWMM Drain }}=$ Routed drain flow $\left(\mathrm{m}^{3} / \mathrm{s}\right)$;

$A=$ Cross-sectional area of the drain $\left(\mathrm{m}^{2}\right)$;

$x=$ Distance along the flow path (m);

$t=$ Time step (s);

$\alpha=$ Flow geometry due to drain (unitless);

$m=$ Surface roughness of drain (unitless).

The study by [30] had recommended to apply the storage unit in SWMM to represent stormwater detention facility, in which it is basically a water balance of water entering $\left(Q_{i}\right)$ and leaving $\left(Q_{o}\right)$ the system over the course of storm $\left(t_{s}\right)$. The storage unit is governed by Equation 5:

$S t=\sum_{i}\left(Q_{i}-Q_{0}\right) \Delta t_{s}$ 
Where,

$S t=$ Storage volume $\left(\mathrm{m}^{3}\right)$;

$Q_{i}=$ Inflow $\left(\mathrm{m}^{3} / \mathrm{s}\right)$;

$Q_{\mathrm{o}}=$ Outflow $\left(\mathrm{m}^{3} / \mathrm{s}\right)$;

$t_{s}=$ Duration of storm (s).

The inflow relates to the flow that is directed from the catchment to the storage unit. On the other hand, the outflow follows the recommendation in [30], in which an orifice diameter $\left(A_{o}\right)$ of $0.05 \mathrm{~m}$ and a discharge coefficient $\left(C_{o}\right)$ of 0.22 were considered suitable to represent the intended modular-based stormwater detention system. Taking the height of storage (excluding the top and bottom covers) at 300 $\mathrm{mm}$, the maximum head to the centre of orifice $\left(H_{o}\right)$ is measured from the design of the said system, which is $275 \mathrm{~mm}$. Acceleration due to the gravity $(g)$ is taken as $9.81 \mathrm{~m} / \mathrm{s}^{2}$. The outflow is governed by Equation 6:

$Q_{o}=A_{o} C_{o} \sqrt{2 H_{o} g}$

Where,

$Q_{o}=$ Flow from the orifice outlet $\left(\mathrm{m}^{3} / \mathrm{s}\right)$;

$A_{o}=$ Orifice diameter $\left(\mathrm{m}^{2}\right)$;

$C_{o}=$ Discharge coefficient of orifice (unitless);

$H_{o}=$ Maximum head to the centre of orifice (m); $g=$ Acceleration due to gravity $\left(\mathrm{m} / \mathrm{s}^{2}\right)$.

\subsection{Modelling approach}

Using SWMM version 5.0, the existing drainage conditions of the study area is modelled (see Figure 7). The authors separated the catchment into ninetynine (99) smaller diagonal polygons representing sub-catchments, in which the flow distributed in the commercial centre can be modelled. The drain is represented by the black dots (nodes) and lines (links).

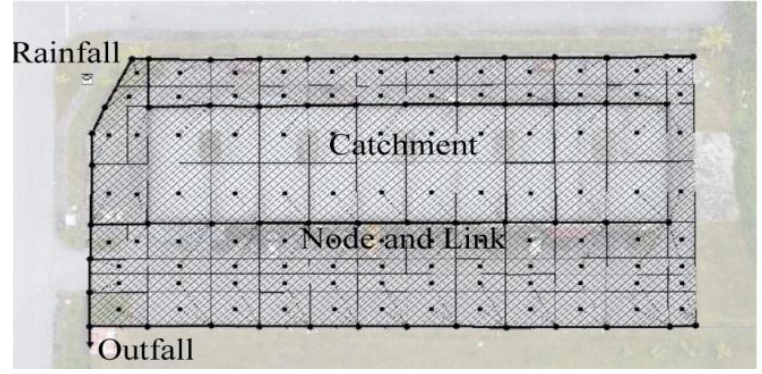

Figure 7 Modelling of existing drainage

The roof is divided into two; the front and back of the roof are considered as separate sub-catchments, assuming the rainwater evenly splits to the front and back of the shops. The road is generally separated based on the crown of the road, assuming the water to flow in two opposite directions. Meanwhile, the road in front of the shops is divided into sub-catchments of parking spaces and carriageway according to the known width of the shops.

Extending from the existing drainage model, scenarios of stormwater control systems are inserted (see Figure 8). The main difference between Figure 7 and Figure 8 is the addition of storage units to represent the modular-based stormwater detention system. Scenario 1 has the detention system at the walkway and its representation could be observed in Figure $8(a)$. Each of the front roof sub-catchment is connected to one storage unit and orifice outlet before discharging to the perimeter drain.

a) 한

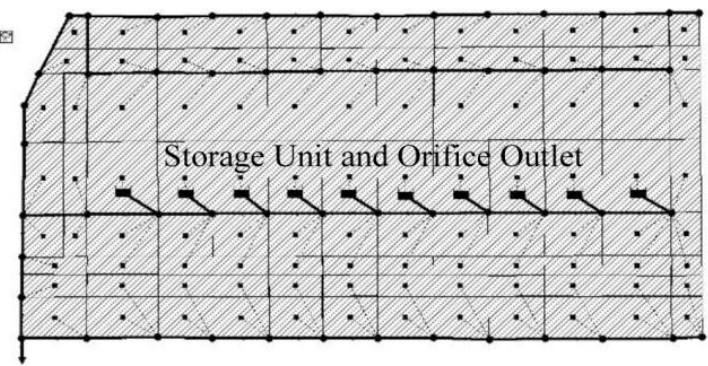

b) 뚠

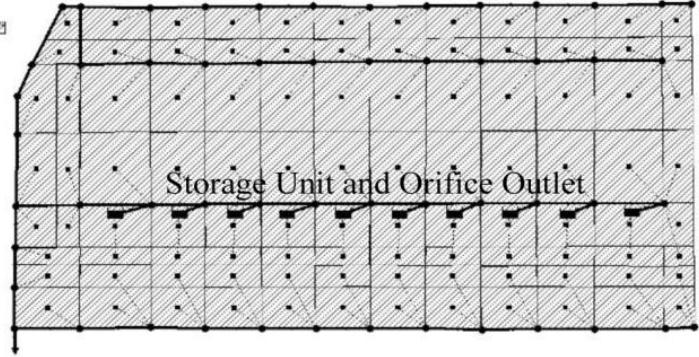

c)

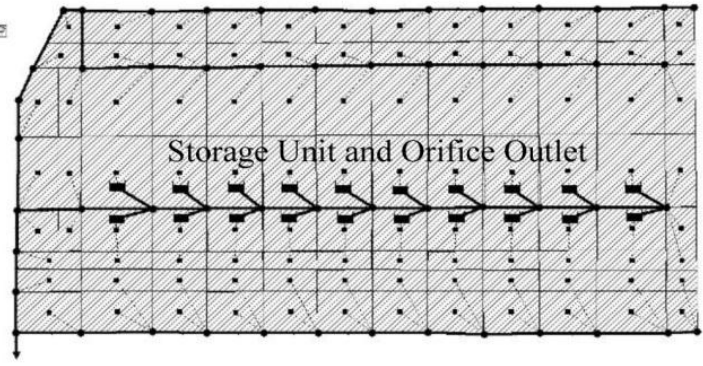

Figure 8 Modelling of stormwater control, a) Scenario 1, b) Scenario 2 and c) Scenario 3

Scenario 2 has the detention system at the parking spaces in front of the shops. This could be observed with the addition of storage units in Figure $8(b)$. Each parking space is provided with a storage unit that receives water from half of the carriageway and the parking space itself before discharging to the 
perimeter drain. Scenario 3 is the combination of the afore-mentioned Scenarios 1 and 2. Representation of Scenario 3 could be observed in Figure 8(c), in which storage units are provided at the walkway and parking space.

\subsection{Control parameters}

No matter which computation methods are used, in this case, the flow mechanism of the dual system could be summarized in a block diagram in Figure 9. Rainfall is a variable here. From the rainfall, it goes to catchments, followed by storage and drain. Therefore, the three components, namely catchment, storage and drain, could be adopted as the control parameters to verify the developed model.

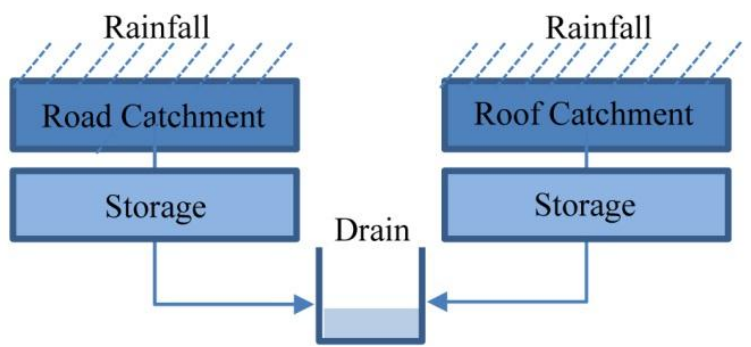

Figure 9 Block diagram of flow mechanism

SWMM does not applied Rational Method in their simulation engine; however, the formula used (Equation 3) is eventually computing the flow out of a catchment, like Rational Method does (Equation 1). As such, values computed from the two formulas are compared in Figure 10. The scatter plot of modelled and theoretical catchment flow data has a high coefficient of determination, R-Squared value of 0.89 .

The storages, in this case, are directly connected to the catchments. Water intercepted by the road catchment is drained to the storage underneath the road; while water intercepted by the roof catchment is drained to the storage under the walkway. As such, these catchment flows are treated as inflow to the storages which could be calculated with Rational Method (Equation 1). Values computed using the formula compared with SWMM (Qi in Equation 5) are presented in Figure 11. Scatter plot of modelled and theoretical storage inflow data has a high RSquared value of 0.94 .

The flow in drain could be manually calculated using the Manning equation (Equation 2). However, the SWMM simulation engine is applying the kinematic wave approximation (Equation 4) to rout the flow in the drain. Comparison of drain flow values using the two methods is presented in Figure 12. Scatter plot of modelled and theoretical drain flow has a high RSquared value of 0.93 .

Generally, an R-Squared value above 0.7 would be perceived as a high level of correlation. The three components above (combining existing drainage system and Scenarios 1 to 3), are found to achieve more than 0.7. As such, the developed SWMM models are substantially verified.

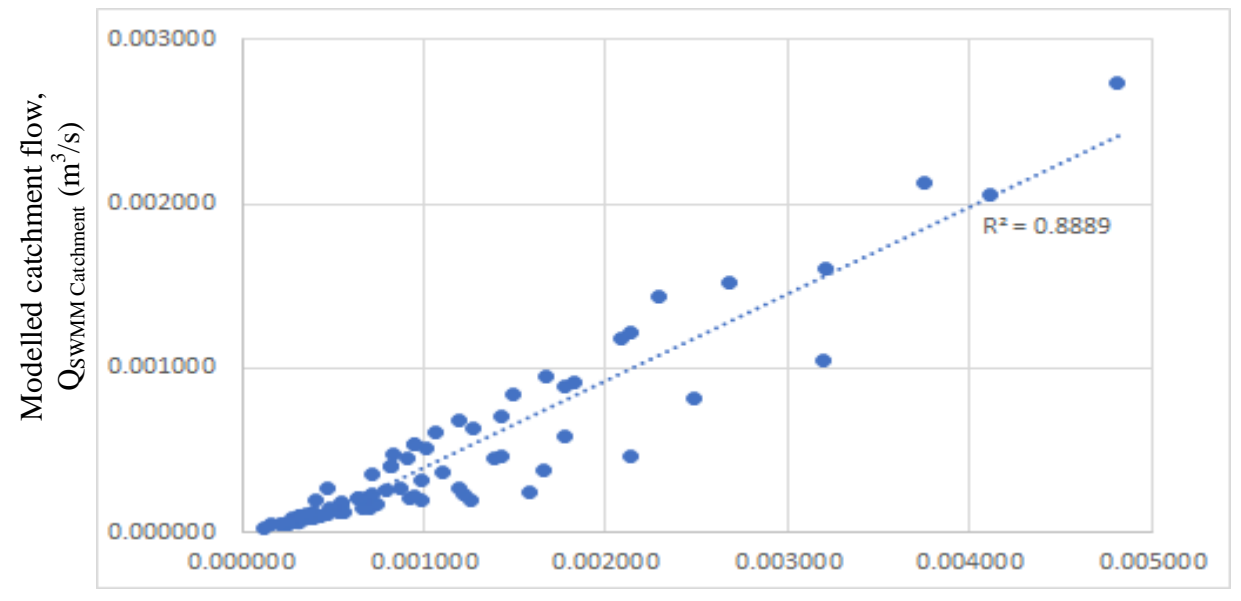

Theoretical catchment flow, $Q_{\text {Rational Method }}\left(\mathrm{m}^{3} / \mathrm{s}\right)$

Figure 10 Scatter plot of modelled and theoretical catchment flow 
Darrien Y.S. Mah et al.

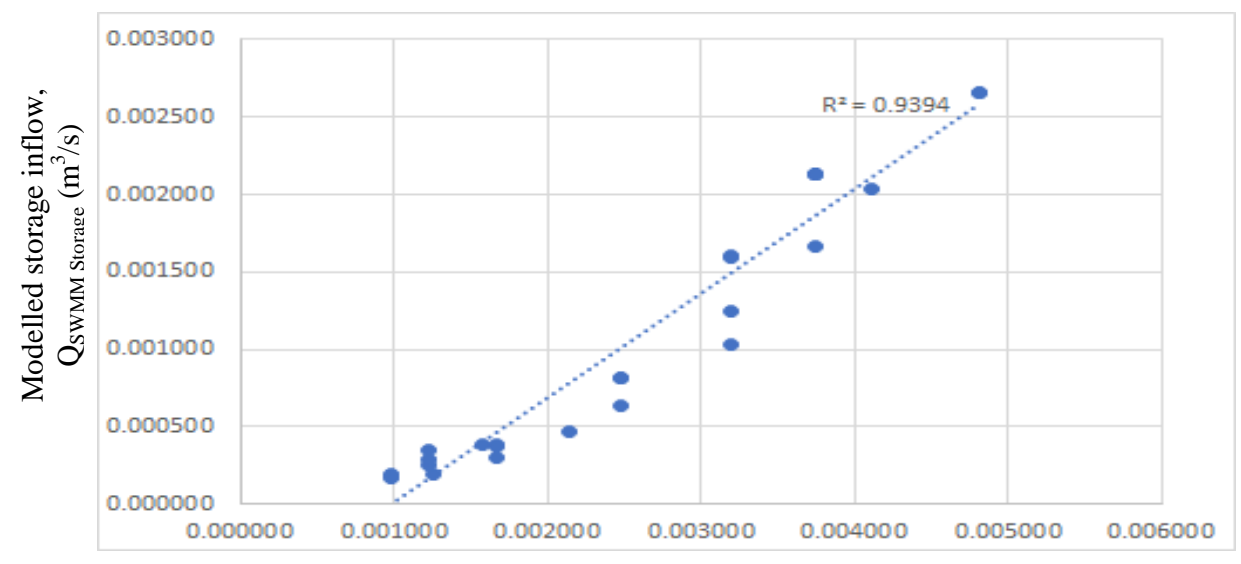

Theoretical storage inflow, $Q_{\text {Rational Method }}\left(\mathrm{m}^{3} / \mathrm{s}\right)$

Figure 11 Scatter plot of modelled and theoretical storage inflow

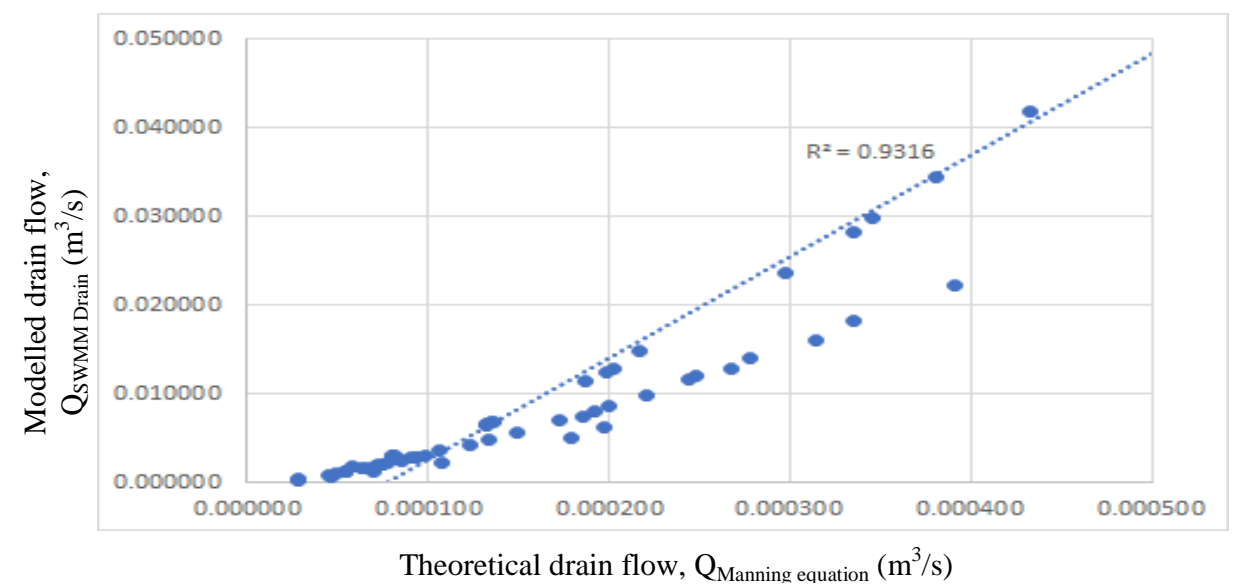

Figure 12 Scatter plot of modelled and theoretical drain flow

\section{Results}

SWMM modelling results are first presented in section 4.1 with an overview of the outcomes from simulating the pre-development, post-development, and the three formulated scenarios. After that, the modelled flows at selected points along the drains are explored in section 4.2. It is then followed by the storages in section 4.3.

\subsection{Outcomes of stormwater control}

To assess the extent of stormwater control due to the proposed measures, the flow data at the outfall are gathered to represent the commercial centre. The modelling results, by referring to Figure 6 , are expected to be in the forms of bell-shaped hydrographs. In this case, five hydrographs are produced representing the pre-development, postdevelopment and three scenarios. However, the hydrographs are difficult to discern and the authors seek a different graphical presentation.
Peak hydrograph values at outfall are gathered, rearranged and plotted as clustered columns in Figure 13. It should be noted that the clusters are based on the selected storm durations. The shorter the storm duration, the more intense the rainfall, and hence the higher the flow generated. Therefore, the 10-min cluster has the most intense rainfall and subsequently the highest flow. The longer the storm duration, the less intense the rainfall, but the wider the time base of the rainfall event. The 180-min cluster has the least intense rainfall among the clusters, subsequently the lowest the flow.

Pre- and post-development peak hydrograph values are calculated based on catchment area and rainfall intensity; and these values are added to the figure for comparison. It is found that the post-development with uncontrolled runoff categories (the second column in each cluster) have the highest flow data across the investigated storm durations. These 
spiking flow values are expected due to the fact that developed areas prohibit water infiltration to the soil, but discharge large amounts of water to the drainage system to cause higher peak flow rates.

Pre-development flow conditions (the first column of each cluster) are the target of stormwater control. Scenarios 1, 2 and 3 have peak hydrograph values above the pre-development conditions for 10 - to 60 min storm durations; and have similar peak values for 120- and 160-min storm durations. However, it is difficult to discern the performances of any of the scenarios using the clustered columns.

The authors find that the stormwater control is related to the catchment areas connected to the proposed system. It is found the higher the connected catchment area, the more the volume of stormwater being detained, hence the higher the achievement of the control. The peak hydrograph values of each scenario are rearranged and plotted into staggered columns in Figure 14. Scenario 2 that connected to about $10 \%$ of the total catchment area has the highest staggered column. This is followed by Scenario 1 in a second highest staggered column that connected to about $20 \%$ of the total catchment area. Scenario 3 with about $30 \%$ of the total catchment area, has the third highest staggered column. Among the three, Scenario 3 is the closest to the pre-development conditions for storm durations range from 10 to 160 minutes. As such, it could be deduced that the dual system in Scenario 3 has better performance than any of the single systems in Scenarios 1 and 2.

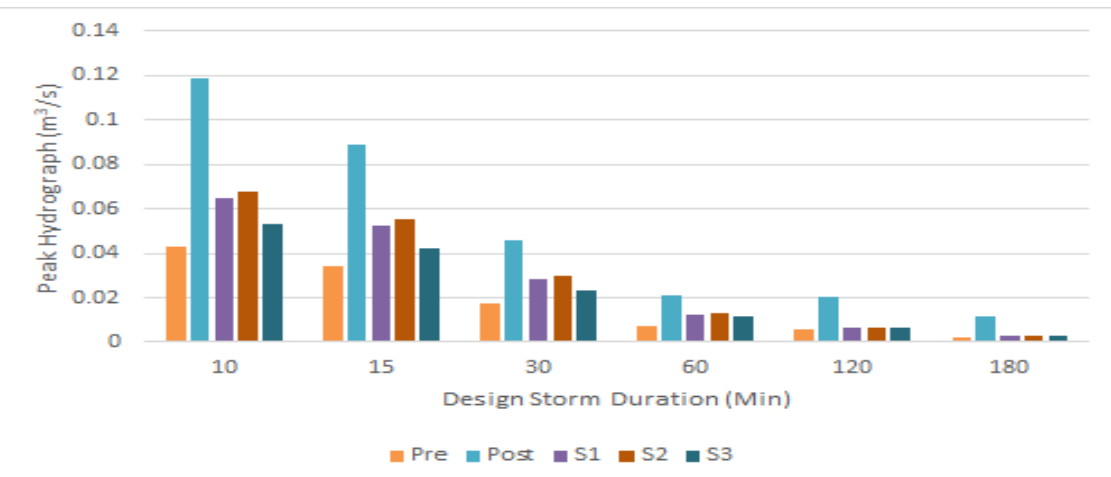

Figure 13 Clustering of peak hydrograph values for pre-development, post-development, Scenario 1, Scenario 2 and Scenario 3 conditions

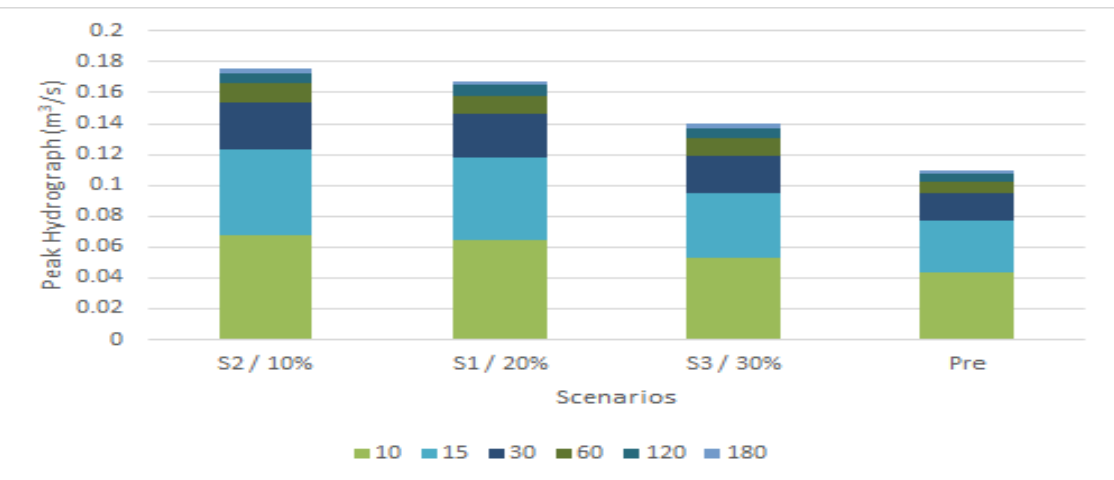

Figure 14 Staggering of peak hydrograph values for pre-development, Scenario 1, Scenario 2 and Scenario 3 conditions

\subsection{Modelled flows in drain}

Modelling the results of Scenario 3 featuring the dual system are compared in Figure 15 with the existing drainage condition. Similar to the descriptions of bar chart cluster in the previous sub-section, the peak hydrograph is found to be the highest in short duration storms, and the peak attenuates as the storm duration increases. The shorter the storm, the narrower the hydrograph shape. Therefore, the longer the storm, the wider the hydrograph shape. 
EXISTING CONDITION

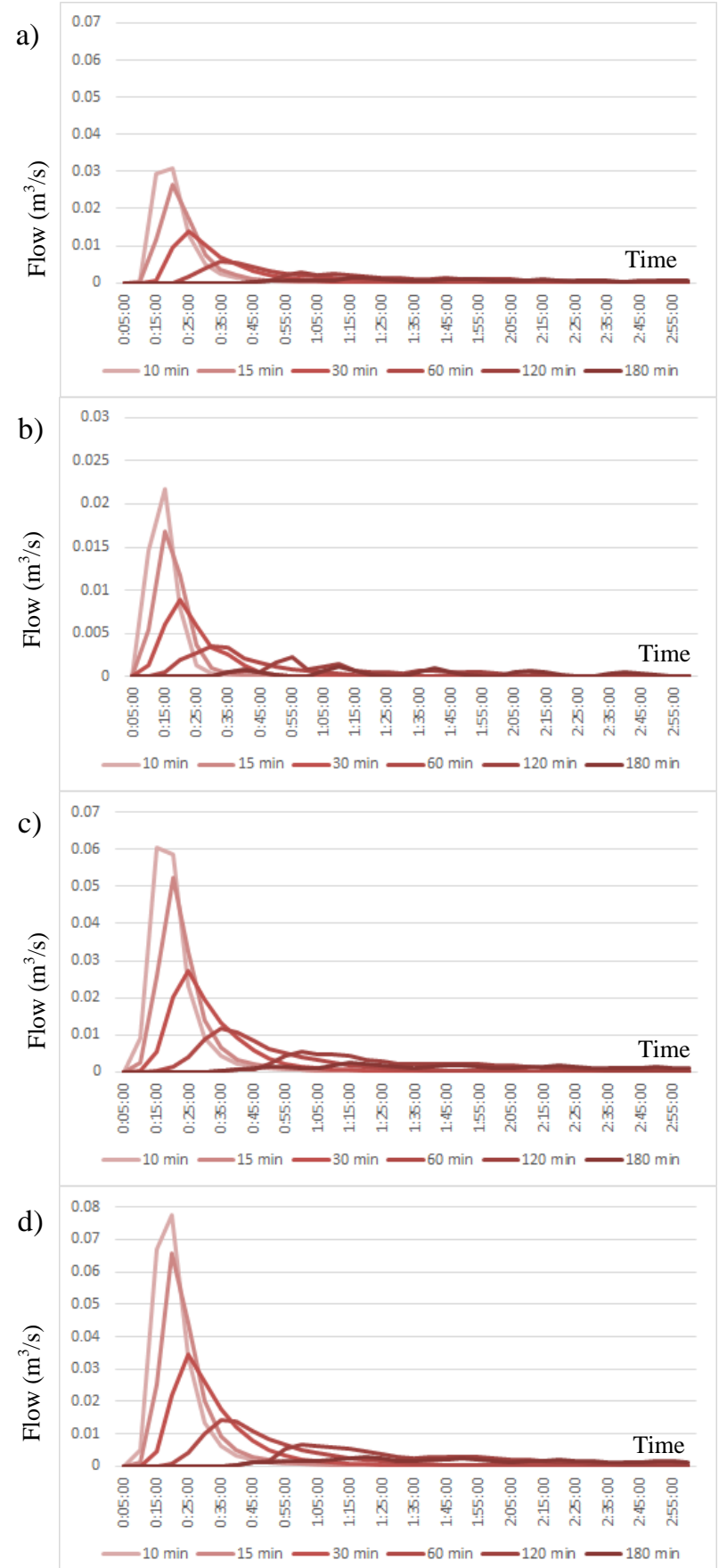

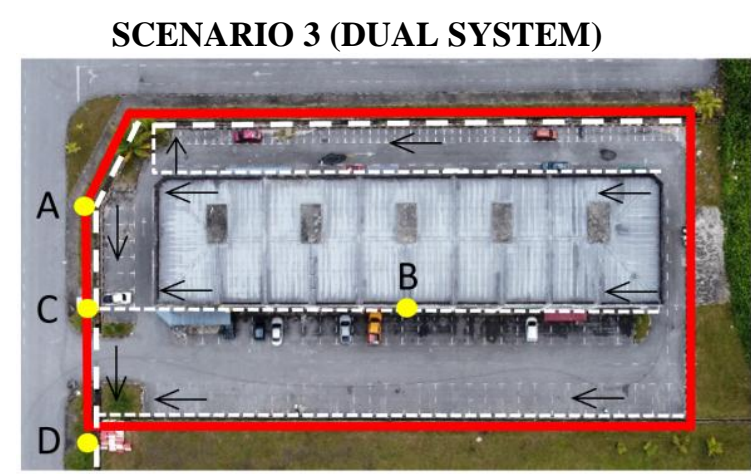

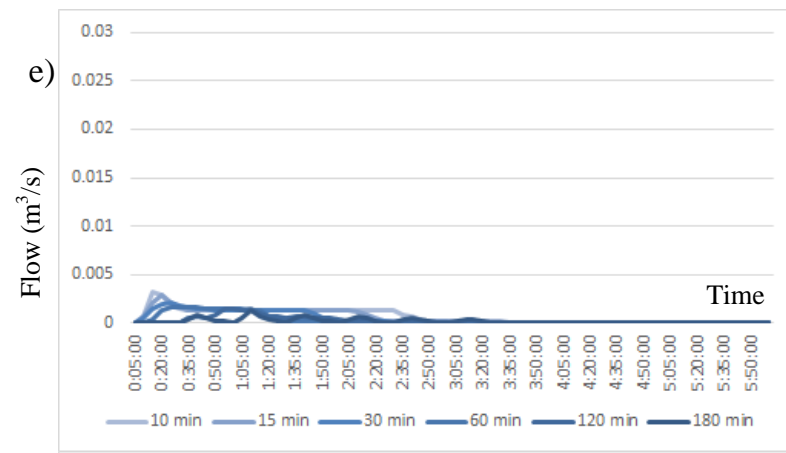

f)

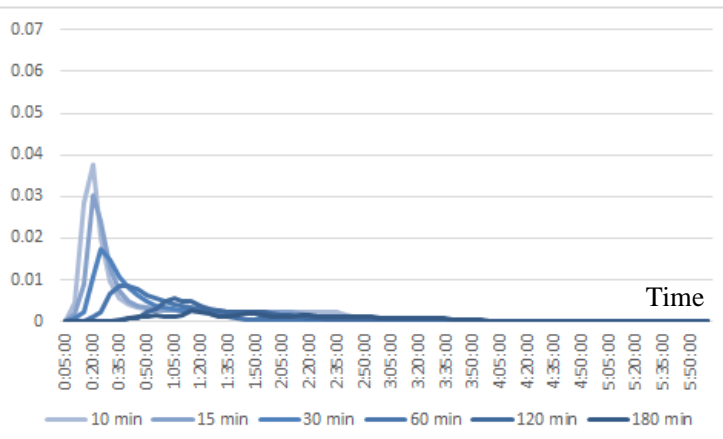

g)

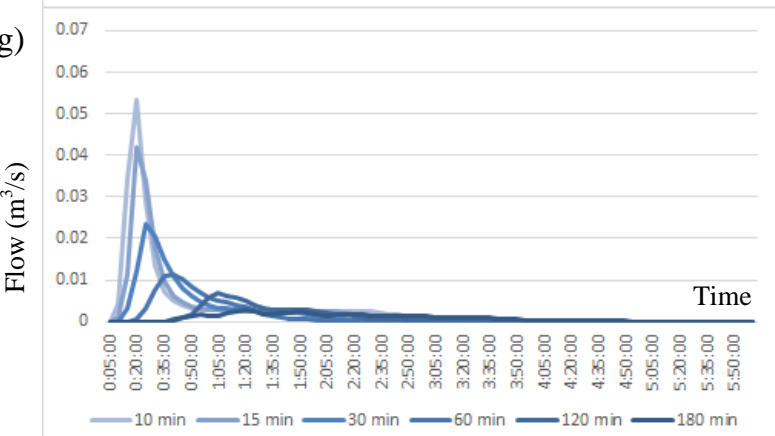

Figure 15 Comparing the results of existing drainage conditions and Scenario 3; Post-development with uncontrolled runoff hydrographs at: a) Location A, b) Location B, c) Location C, d) Location D; Post-development with controlled runoff hydrographs at: e) Location B, f) Location C, and g) Location D; Inlet: Indicator of locations

Four (4) points along the drain in the commercial centre are illustrated in the inlet of Figure 15. In this figure, Location A receives flow from the back roof and back lane sub-catchments, in which these catchments are not affected by any of the stormwater 10 control systems. The flow from the location in Figure $15(a)$ is merely contributed by the flow upstream. The hydrographs are the same for all scenarios, and thus are not repeated in Figure 16. 
SCENARIO 1

a)

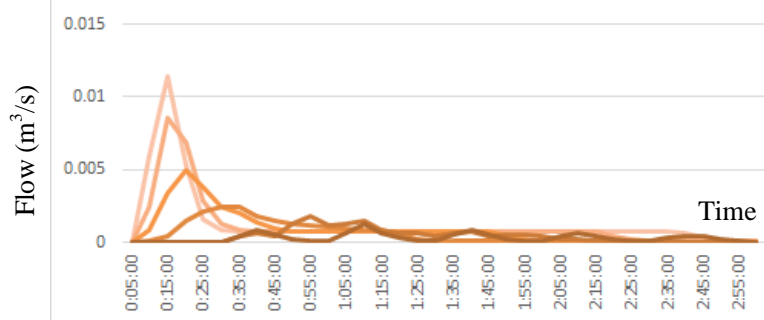

b)

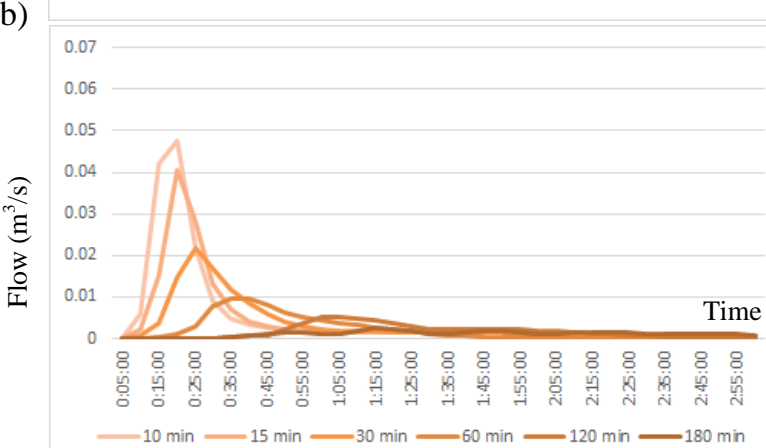

c)

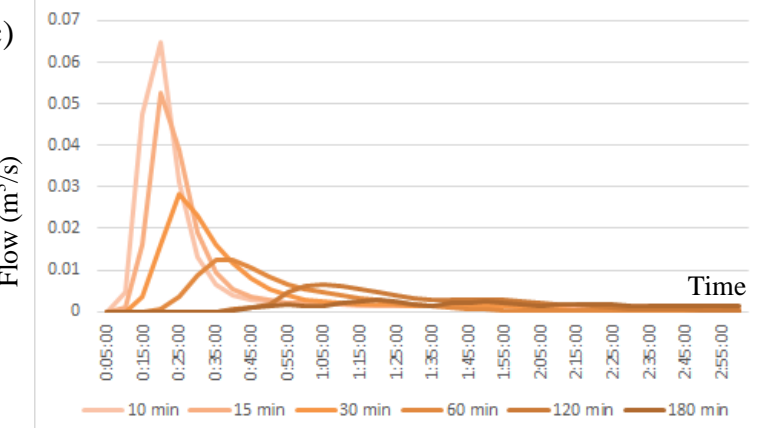

SCENARIO 2

d)

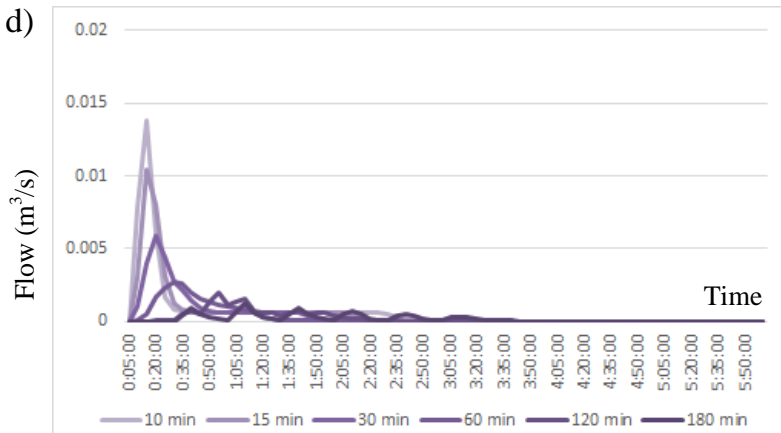

e)
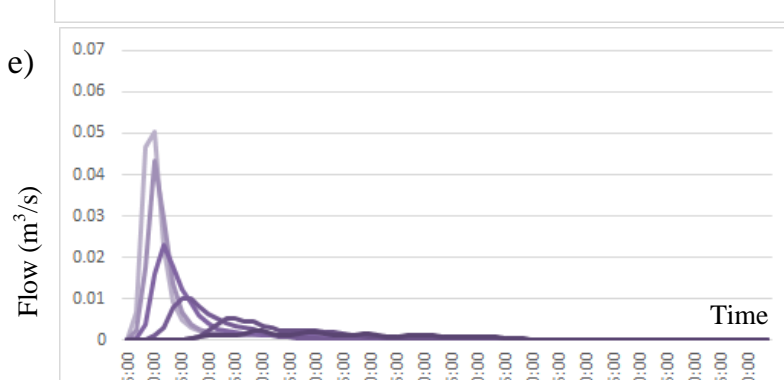

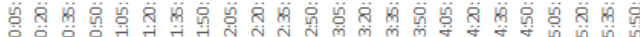
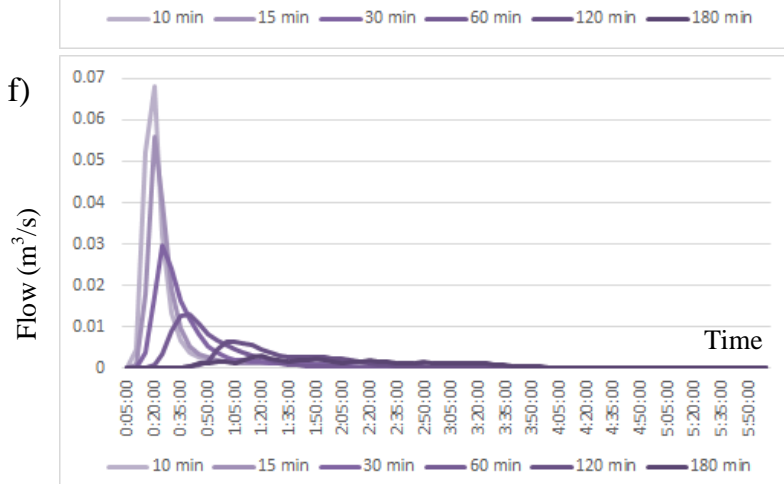

Figure 16 Post-development with controlled runoff hydrographs for Scenario 1 at: a) Location B, b) Location C, c) Location D; Post-development with controlled runoff hydrographs for Scenario 2 at: d) Location B, e) Location C, and f) Location D

Location $\mathrm{B}$ is the mid-point for the $74 \mathrm{~m}$ perimeter drain in front of the shops. With the dual system in place, the peak hydrographs for 10-, 15- and 30-min storm durations are lowered to below $0.005 \mathrm{~m}^{3} / \mathrm{s}$ (Figure 15(e)) compared to the existing conditions (Figure 15(b)). Take the example of 10-min storm duration, the reduction is 4 times more when the water detention structure is introduced. This reduction results in less water flowing downstream.

Location $\mathrm{C}$ is the confluence point of water flowing from Locations A and B. With less water from Location $\mathrm{B}$, the downstream peak hydrographs are reduced. Take the 10 minutes, a reduction of around 1.5 times to $0.04 \mathrm{~m}^{3} / \mathrm{s}$ (Figure $15(f)$ ) is noted compared to the existing conditions at $0.06 \mathrm{~m}^{3} / \mathrm{s}$ (Figure 15(c)).

Location D is the final discharge point that represents the flow of the whole commercial centre. Here, at 10-min duration, 1.5 times reduction is also registered when comparing the controlled scenario at $0.05 \mathrm{~m} 3 / \mathrm{s}$ (Figure $15(\mathrm{~g})$ ) with the uncontrolled scenario at $0.08 \mathrm{~m} 3 / \mathrm{s}$ (Figure $15(d))$.

Figure 16 shows the hydrographs computed from Scenarios 1 and 2. Each of these scenarios has either Scenario 1 or Scenario 2 inserted in the models. Although those from Scenario 1 is slightly lower than Scenario 2, the differences are small. It could be 
deduced that the peak hydrographs resulted from these two scenarios are similar. Comparing Figure 16 with Figure 15, it could be observed that the peak hydrographs from Scenarios 1 and 2 are following closely with the existing conditions. It points to a small reduction of peak hydrographs when compared with the existing conditions.

\subsection{Detained water level patterns}

Nevertheless, regardless of the scenarios, the rainwater is well contained within the detention system. Noting that the maximum depth of the underground storage is $0.3 \mathrm{~m}$, the detained water levels are found below the maximum depth (Figure 17). As such, no overflowing is predicted from the system. Generally, the shorter the storm, the higher the water level in the detention system. This is due to the fact, shorter storms come with higher rainfall

\section{SYSTEM 1 (WALKWAY)}

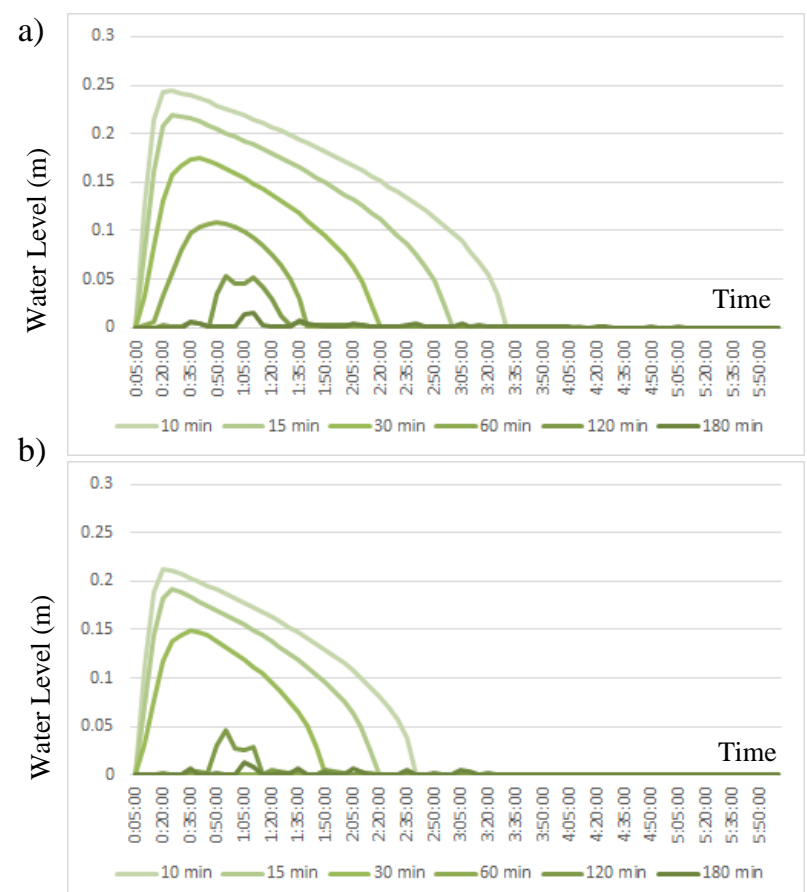

depths. Over the short time, water surges to a high level. In contrary, longer storms come with lower rainfall depths, in which water enters the detention slowly and discharges at the same time. Therefore, no drastic surges of water level are observed for longer design storm durations.

The storage units are divided according to the shop lot's width. The authors named them according to corner and intermediate lots. The storage unit associated with the corner lot has a slightly bigger surface area than the one associated with intermediate lot. Comparing Figures 17(a) and 17(b) for detention under the walkway, the differences of the two are considered small, therefore it could be classified as similar patterns.

Figure 17 Water level in the modular stormwater detention system for, a) Walkway in front of corner shop, b) Walkway in front of intermediate shop. c) Parking space in front of corner shop, and d) Parking space in front of intermediate shop

Comparing Figures $17(c)$ and $17(d)$ for under the parking space, both figures are all most identical. This is due to the same orifice outlet size being used. According to Equation 6, the outflow of the system is a function of the orifice size.
Furthermore, the time series of water level fluctuation are different due to the effective storage volume between the two systems. It is found that the lower effective storage volume for the detention under the walkway causes a higher water level than the detention under the parking space. 


\section{Discussion}

First of all, the storm durations ranging from 10 to 160 minutes are the various rainfall intensity levels under 10-year ARI design rainfall. The shortest among the selected durations, namely the 10 minutes, is a test of the proposed system subjected to a sudden surge of water. It is found that the proposed system could contain the surge well and it is reflected in Figure 17, particularly Figure 17(a) which the highest water level being estimated is $0.25 \mathrm{~m}$ against the maximum depth of the detention system at $0.3 \mathrm{~m}$. On the other hand, the longest among the selected durations, namely the 160 minutes, is a test of the durability of the system. The system is found to withstand up to the 3-hour storm. This is made possible because the detention system is not designed to hold all possible generated water which requires a large structure. Instead, our system is intended as a draining water tank. The captured water is allowed to be drained out at the same time. With its relatively small and compact sizes, the required detention is still achieved. It is proven in Figure 14, in which Scenario 2 achieves nearest to the target (predevelopment) across all storm durations.

It is highlighted that the achievements of storm control are highly related to the catchment area connected to the proposed system. The systems for all scenarios are placed at the front of the shoplots. Then, it is understandable that there are catchments like the back roof and back lane catchments that are not connected or not practical to be connected to the proposed system. The immediate effect of the detention system could be observed at the front drain of the shoplots. With the water being captured, it is reflected in Figure 15(e) under Scenario 3 that the hydrographs are significantly lowered at Location B. Other scenarios at the same location do not have the similar extravagant reduction.

Although the reduction is great at Location B for Scenario 3, the overall flow at the outfall (Location D) after combining flows from the other nonconnected catchment is found to overshadow the reduction. For Scenario 3, the non-connected catchments consist of $70 \%$ of the commercial centre. Other scenarios are even higher. Scenario 1 has $80 \%$ non-connected catchments, while Scenario 2 has $90 \%$. These high percentages of non-connected catchments are continuing "business as usual" to discharge to the drains.

Despite so, the stormwater control achieved by Scenario 3 is still commendable. The flow data in
Scenario 3 are the nearest to the flow data generated under pre-development condition. The range of flow data has a difference of $24 \%$ in average compared to the flow data on pre-development condition. The other two scenarios are even further apart from the target. Scenario 3 has a difference of $41 \%$ in average, while Scenario 1 has $46 \%$ when compared to predevelopment condition.

The limitation in the current investigation is the exclusion of water infiltration to soil. Detention structures could allow infiltration of partial captured water to the soil layer surrounding the proposed system in each of the scenarios. However, infiltration process is highly depending on the soil types. For example, clayey soil has generally low infiltration rate, while sandy soil has a relatively higher infiltration rate than the clayey type. The information about the soil types and its associated infiltration rates are lacking at the time of writing. Should the soil in the study area is of sandy type, then it is expected to improve the stormwater control by removing water to the soil, hence lesser water is being discharged to the drain. The hydrographs are also expected to be lower. A complete list of abbreviations is shown in Appendix I.

\section{Conclusion}

A dual stormwater detention system is presented in this paper utilizing real-world spaces of the walkway and parking spaces in front of existing shop lots. The dual system is subjected to 10-year ARI design rainfall with six storm durations, namely $10,15,30$, 60,120 and 160 minutes. It is found that by using the dual system, the post-development peak hydrograph with uncontrolled runoff could lower most for all the aforementioned storm durations, rather than separating them into two single systems either on a walkway or parking spaces.

\section{Acknowledgment}

The authors acknowledged the financial support from the SDG Research@Borneo grant scheme (Project ID GL/F02/MCUN/14/2020), rendered by the Malaysian Comprehensive University Network (MCUN).

Conflicts of interest

The authors have no conflicts of interest to declare.

Authors contribution statement

Darrien Y.S. Mah: Data collection, SWMM modelling, analysis, interpretation of results, paper writing. Janice Lynn Ayog: Interpretation of results, review and editing. Afdal Haziq Mohamad Salehe: Dual stormwater detention system design, technical drawing, 3D drawing. 


\section{References}

[1] Frame DJ, Rosier SM, Noy I, Harrington LJ, Careysmith T, Sparrow SN, et al. Climate change attribution and the economic costs of extreme weather events: a study on damages from extreme rainfall and drought. Climatic Change. 2020; 162(2):781-97.

[2] Zha X, Luo P, Zhu W, Wang S, Lyu J, Zhou M, et al. A bibliometric analysis of the research on sponge city: current situation and future development direction. Ecohydrology. 2021.

[3] Li C, Fletcher TD, Duncan HP, Burns MJ. Can stormwater control measures restore altered urban flow regimes at the catchment scale? Journal of Hydrology. 2017; 549:631-53.

[4] Xu WD, Burns MJ, Cherqui F, Fletcher TD. Enhancing stormwater control measures using realtime control technology: a review. Urban Water Journal. 2021; 18(2):101-14.

[5] Radinja M, Comas J, Corominas L, Atanasova N. Assessing stormwater control measures using modelling and a multi-criteria approach. Journal of Environmental Management. 2019; 243:257-68.

[6] Thom JK, Szota C, Coutts AM, Fletcher TD, Livesley SJ. Transpiration by established trees could increase the efficiency of stormwater control measures. Water Research. 2020.

[7] Erickson AJ, Taguchi VJ, Gulliver JS. The challenge of maintaining stormwater control measures: a synthesis of recent research and practitioner experience. Sustainability. 2018; 10(10):1-15.

[8] Hong YM. The simplified design method of permeable pavement system for urban catchment. Environmental Challenges. 2021.

[9] https://darrohnengineering.com/civilengineering/civil-engineering-explained-what-is-adry-pond/. Accessed 27 July 2021.

[10] https://www.mwmo.org/learn/visit-us/tree-trench/. Accessed 24 July 2021.

[11] https://www.reimangardens.com/educationideas/sustainability/rain-barrels/. Accessed 24 July 2021.

[12] Ibrahim YA. Managing stormwater as a complex adaptive system. Journal of Hydrologic Engineering. 2019; 24(10).

[13] Ebrahimian A, Sokolovskaya N, Wadzuk B. Modeling dynamic performance of urban infiltration trench systems: methodology and a case study in Philadelphia. Journal of Hydrology. 2021.

[14] Sobirin A, Sutjiningsih D. The role of green infrastructure in reducing runoff in urbanized catchment areas of Eastern Jakarta. In conference series: earth and environmental science. 2019 (pp. 18). IOP Publishing.

[15] Araujo MC, Leão AS, De JTB, Cohim E. The role of rainwater harvesting in urban stormwater runoff in the semiarid region of Brazil. Urban Water Journal. 2021; 18(4):248-56.

[16] Lestari E, Kinasti RM, Putri D. Utilization of rainwater harvesting for groundwater conservation in educational building. In conference series: materials science and engineering 2020 (pp. 1-6). IOP Publishing.

[17] Sharma AK, Gardner T. Comprehensive assessment methodology for urban residential rainwater tank implementation. Water. 2020; 12(2):1-20.

[18] Antunes LN, Ghisi E, Severis RM. Environmental assessment of a permeable pavement system used to harvest stormwater for non-potable water uses in a building. Science of the Total Environment. 2020.

[19] Martins VIC, Ghisi E, Thives LP. Stormwater harvested from permeable pavements as a means to save potable water in buildings. Water. 2021; 13(14):1-22.

[20] Lee SH, Kim JS, Kim SJ. Analysis of applicability of the detention in trunk sewer for reducing urban inundation. Ecology and Resilient Infrastructure. 2021; 8(1):44-53.

[21] Gomes JMN, Mendiondo EM, Dornelles F, Papagiannakis AT, Giacomoni MH. Permeable pavement hydrological model to assess the long-term efficiency of maintenance using high-resolution temperature and rainfall data. In world environmental and water resources congress 2021 (pp. 1103-17).

[22] Ellis JR, Biessan DG, O'donnell FC, Vasconcelos JG, Bowers BF. Developing a practical tool for integrating green infrastructure into cost-effective stormwater management plans. Journal of Hydrologic Engineering. 2022; 27(2).

[23] Xiong L, Yan L, Du T, Yan P, Li L, Xu W. Impacts of climate change on urban extreme rainfall and drainage infrastructure performance: a case study in Wuhan city, China. Irrigation and Drainage. 2019; 68(2):15264.

[24] https://www.pub.gov.sg/Documents/detentionTank.pd f. Accessed 24 July 2021.

[25] DID (Department of Irrigation and Drainage). Urban stormwater management manual for Malaysia. 2012.

[26] Guo X, Guo Q, Zhou Z, Du P, Zhao D. Degrees of hydrologic restoration by low impact development practices under different runoff volume capture goals. Journal of Hydrology. 2019.

[27] Ouyang Y, Zhang J, Feng G, Wan Y, Leininger TD. A century of precipitation trends in forest lands of the lower Mississippi river alluvial valley. Scientific Reports. 2020; 10(1):1-16.

[28] Mah DY, Ngu JO, Bustami RA, Putuhena FJ. Case study of modular pre-cast concrete on-site stormwater detention system during monsoon season in southeast Asia. Applied Environmental Research. 2021; 43(1):28-40.

[29] Mah DY, Ngu JO, Taib SN, Mannan MA. Modelling of compartmentalized household stormwater detention system using SWMM5. International Journal of Emerging Trends in Engineering Research. 2020; 8(2):344-9.

[30] Mah DY, Ngu JO, Bateni N, Putuhena FJ. Modelling the outlet of multi-chamber stormwater detention system. Science \& Technology Asia. 2021:77-89. 


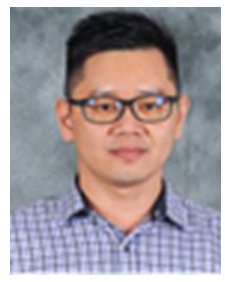

Darrien Y.S. Mah is an associate professor with the Department of Civil Engineering, Faculty of Engineering, Universiti Malaysia Sarawak. $\mathrm{He}$ obtained his $\mathrm{PhD}$ degree from Universiti Malaysia Sarawak. His research interest is Water Resources Modelling.

Email: ysmah@unimas.my

\begin{tabular}{lll}
\multicolumn{2}{l}{ Appendix I } \\
\hline S. No. & Abbreviation & Description \\
\hline 1 & ARI & Average Recurrent Interval \\
\hline 2 & SWMM & Storm Water Management Model \\
\hline
\end{tabular}

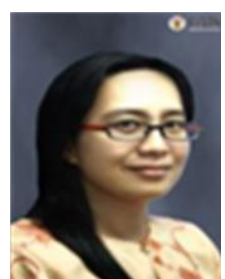

Ms. Janice Lynn Ayog is a lecturer with the Faculty of Engineering (Civil Engineering), Universiti Malaysia Sabah. She is also a $\mathrm{PhD}$ candidate with the University of Sheffield, UK. Her research interest is Water Resources Modelling.

Email: jay@ums.edu.my

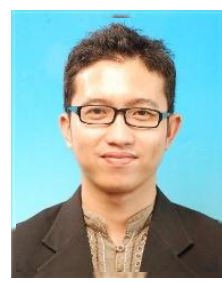

Mr. Afdal Haziq Mohamad Salehe is the founder and Managing Director of Syarikat Haziq Jaya Pvt Ltd. He obtained his Master of Civil Engineering from Universiti Malaysia Sarawak. His research interest is Civil Engineering Related Technology.

Email: afdalhaziqms@gmail.com 